1866 with a thesis on death from cardiac concretions in diphtheria, and then set up in practice in his native town, where he remained until his death on September 6, 1914, except when he served as a medical officer in the French army during the FrancoPrussian War. He was for several years mayor of Ferney, where the high esteem in which he was held led to his being created a knight of the Legion of Honour. Gerlier is best known for his classical description of epidemic paralysing vertigo, to which his name has been given. His first account of the disease was given in 1886 before the Medical Society of Geneva, of which he was a corresponding member, and was published the next year in the Revue médicale de la Suisse Romande, his subsequent papers on this subject appearing in this journal in 1888 and $189 \mathrm{I}$ and in the Archives generales de medecine in 1899 .

The disease has a very limited geographical distribution, being found only in the Pays de Gex on the Franco-Swiss frontier and in Japan, where it is called kubisagri and has been studied by Couchoud, who regards it as due to a small coccus. Outbreaks take place in May or June, reach their acme in the summer and come to an end in the autumn. The disease has been found in cats and fowls and appears to be causally connected with close contact with horses and cattle, although they do not contract the disease. The symptoms consist in sudden attacks of vertigo and generalized muscular weakness accompanied by diplopia and amaurosis, and lasting for about ten minutes. Nothing definite is known as to the pathology of the disease, and there is no specific treatment.

\section{Antiquities from the Northumberland Collections}

Two important and interesting specimens from the Egyptian and western Arabic collection of antiquities belonging to the Duke of Northumberland recently removed from Alnwick to be placed on loan in the British Museum have been described and figured by Mr. Sidney Smith (Brit. Museum Quarterly, $14,2 ; 1940)$. Of these the first is an 'elegant vase' for cosmetics in the shape of a naked slave girl carrying a vase and walking on a pedestal. It was described many years ago by Samuel Birch, keeper of the Department of Egyptian Antiquities in the British Museum, in his catalogue of the collection. $\mathrm{He}$ did not, however, as Mr. Smith points out, fully appreciate the singular interest of the figure. Except for a wooden statuette in the Louvre, there is no other example of a similar treatment of movement of the body among such wooden figures. The material has been identified as a boxwood from the Lebanon, and while the Louvre male figure has been assigned to the Eighteenth Dynasty from its resemblance to Syrian figures depicted in the tombs, the figure of the girl is not likely to belong to the early part of the dynasty but is assigned to the reign of either Amenhotep III or Tutankhamen.

The second exhibit described is a cylinder seal of hematite of a shape common in the fifteenth century B.c. and later. Its singular importance and unique character lie in the fact the men and bird depicted on it lie outside the known categories of themes on cylinder seals, yet the seal itself and some elements are normal in Syria about the middle of the second millennium. The men wear light waist-belts and a short kilt flounced, which resembles, though it is not identical with, the Cretan wear for athletes. Mr. Smith suggests that it is not a sufficient explanation of the seal to say that it shows Cretan influence, but that it looks as if a Babylonian seal-cutter was actually depicting men in Syria who wore something like Cretan dress, and copied for this purpose such figures as the running men from foreign art. If this be accepted, this seal and the Egyptian figures throw an interesting sidelight on the spread and distribution of artistic activities and motifs in the world of the ancient East in the second millennium B.c.

\section{The Royal Asiatic Society or Bengal}

A RECENT reorganization in the administration and installation of the Royal Asiatic Society of Bengal, which is set out in detail in the recently issued annual report (Year Book for 1939, 6 ; 1940) has already borne fruit, more especially in a speedingup of publications which had been allowed to fall in arrear. It is possibly to be attributed to the same quickened interest in the work of the Society that the exhibits shown at its annual meeting on February 5,1940 , attracted exceptional attention, notably in anthropology and archæology, subjects upon which as studied in India criticism has recently been directed with no little vigour from more quarters than one. Of the ethnographical exhibits the most striking was a small collection of the wooden effigies erected in memory of the dead by the Red Kaffirs of the Hindu Kush. These effigies came from the village of Rambur and were collected by members of the Zoological Survey of India in 1929. One represented a man riding a horse and the other a woman wearing the characteristic horned headdress of the Red Kaffir women. It may be of interest to note that it has been suggested that these figures may have some relationship to certain of the wellknown Easter Island figures, of which the origin and purpose have been the subject of much discussion.

Another exhibit of considerable interest was a collection of human skeletal remains recently excavated by the Archæological Department of Gwalior State on a Mauryan site at Kumbar Tekri near Ujjain. With the exception of those found by Sir John Marshall at Taxilla, these are the only human skeletal remains of the Historical Period, which have as yet been brought to light by archæological excavation. It is noteworthy that the great development of the posterior parts of the skull characteristic of the big-brained races of the chalcolithic Indus Valley civilization is not found in the skulls of the Historic Period.

\section{New Regulations for Pharmaceutical Examinations}

NEw regulations governing the conditions prerequisite to pharmaceutical qualifications have been made by the Council of the Pharmaceutical Society. The work of revision began in 1936 and the subcommittee which was appointed for the purpose was assisted in its deliberations by representatives of the 
Ministry of Health and the Department of Health for Scotland and by the external registrar of the University of London. The revised regulations, which affect both the Society's examinations and the curriculum of study, will come into operation in October, subject to the approval of the Privy Council. The syllabuses for the Preliminary Scientific Examination, to be known in future as the 'Intermediate Examination', have been simplified to some extent and the changes are in favour of candidates rather than otherwise ; for example, organic chemistry will not be taken at this stage in future. The physiology of heterotrophic plants has been deleted from the botany syllabus and saprophytism and parasitism have been added. The wording of the zoology syllabus has been modified with the object of limiting the knowledge which the candidate should possess of histology and otherwise of indicating that attention should be directed mainly to types and not to groups to which the types belong. More important, however, is the provision that the Council of the Pharmaceutical Society may require that the Intermediate Examination shall be passed before the student commences his practical training in a pharmacy or a hospital ; this provision is wisely conceived, for the present high percentage of failures clearly suggests that many candidates would be well advised to choose some career other than pharmacy.

With regard to the Qualifying Examination, there has been some unloading of the syllabuses, but this does not appear to reduce the general standard of requirements. In pharmaceutical chemistry the candidate's knowledge of tests for purity and of chemical assays will in future be limited to those of the British Pharmacopoia and, in pharmaceutics, the reference in the syllabus to the biological standards of galenical preparations has been deleted, as the principles underlying these subjects are more appropriately treated in physiology and pharmaceutical chemistry respectively. The changes affecting the Pharmaceutical Chemist's Examination include, in the pharmaceutical chemistry syllabus, the substitution of "adrenaline, thyroxine, vitamins $A, B_{1}$ and $B_{2}, C$ and $D$ " for the crystallizable hormones and vitamins and, in the pharmaceutics syllabus, the addition of the factors involved in transferring small-scale pharmaceutical operations to a large scale. The preparation of bacterial vaccines has been deleted, and disinfectants and the factors governing their efficiency have been added to the syllabus. Another addition is a knowledge of the physiological properties of vitamins. In the requirements for this higher examination, the object of the changes would appear to be directed to an adjustment to more recent developments in sciences allied to pharmacy.

\section{British Birds in 1939}

A NUMBEr of local societies have recently issued their field records of bird-life in 1939. The London Natural History Society's Bird Report for 1939, issued separately from the London Naturalist for the fourth year, covers bird-life within twenty miles of St. Paul's Cathedral and notes more than 160 different species, including such uncommon visitors as the firecrest, great grey shrike, purple sandpiper and Iceland gull, a summary of the arrival dates of migrants for eight years and special accounts of the status of the goldfinch, stock-dove, sandpiper and redshank. The Merseyside Naturalists' Association's 1939 notes from Liverpool (Ibis, July) add the Kentish plover to the Laneashire list and the roseate term to the Cheshire list, in addition to noting such uncommon visitors as the red-necked grebe, black redstart, velvet scoter and a mid-winter record of the little stint, as well as extensions of the nesting range of tufted duck, pochard and herring-gull.

In the home counties, the Oxford Ornithological Society notes the blue-headed wagtail at Slough Sewage Farm, Bucks, in May, June and July, as well as visits of grey plover, turnstone and knot, wh le in East Anglia, the Norfolk and Norwich Naturalists' Society Bird Report mentions two pairs of marshharriers at Hickling and Horsey but only one nest known to rear young, no Montagu's harriers and only about four pairs of bearded tits, a whiskered tern at Hitchling in June and a sight record of the Mediterranean Black Headed Gull in October. A pair of roseate terns nested at Blakeney and dunlin again at Clay, but the latter apparently not rearing young. The Cambridge Bird Club notes bittern, Montagu's harriers and black-necked grebes on Burwell Fen, but not nesting, nor was the black redstart again found nesting in its 1938 haunt. The Yorkshire Naturalists' Union report (Naturalist, 1940, pp. 7-18) notes the siskin nesting at Goathland, pintail at Skipworth, and the crossbill at Thornton Dale; goshawk, water-pipit, an immature white-tailed eagle, ospreys and red-legged partridge were uncommon records. The nesting of the arctic tern at Spurn is believed to be a county record.

\section{Public Health Progress in India}

The July issue of the Asiatic Review contains an interesting article by Sir Alexander Russell, formerly medical officer of health and professor of hygiene and bacteriology at Madras, on public health progress in India during the last forty years. Since 1911, research work under the auspices of the Indian Research Fund Association has been chiefly connected with India's public health problems and considerable achievements. have been recorded, especially as regards plague, cholera, malaria, kala-azar and nutrition, while investigations on the indigenous drugs of India have done much to determine their therapeutic action. The Research Association has also supplied means. for the training in research of a large number of Indian graduates of science and medicine. An All-India League was formed in 1921 to promote maternity and child-welfare throughout the country. In 1930 it became the Maternity and Child Welfare Bureau, and now in most provinces the work is carried on either through the official health departments or by voluntary organizations.

The Institute of Hygiene and Public Health provides a course of instruction and a diploma in maternity and child-welfare, while half a dozen 